\section{Integrerende om psykoterapi}

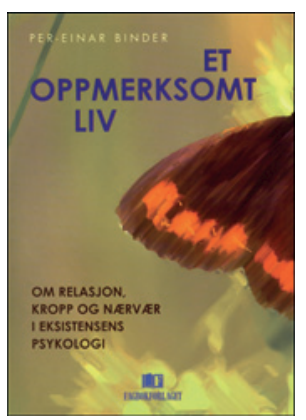

Per-Einar Binder

\section{Et oppmerksomt liv}

Om relasjon, kropp og nærvær i eksistensens psykologi. 247 s, ill. Bergen: Fagbokforlaget, 2011. Pris NOK 369

ISBN 978-82-450-1164-7

Per-Einar Binder (f. 1967), professor i klinisk psykologi i Bergen, har i noen år gjort seg gjeldende som forsker og kliniker hva gjelder kvalitative studier av psykoterapiprosesser og andre endrings- og utviklingsprosesser. Han interesserer seg for psykodynamisk (relasjonell), emosjonsfokusert og eksistensielt orientert psykoterapi, i tillegg til bruk av metoder for å oppnå oppmerksomt nærvær (mindfulness) i kombinasjon med annen form for psykoterapi. I denne boken er hensikten tydeligvis å kombinere erfaringer fra disse ulike psykoterapeutiske tilnærmingene til en integrert praksis som han kaller eksistensens psykologi.

Man kunne frykte at en målsetting om å integrere så mange ulike perspektiver på hva som kan fremme endring, ville resultere i en salig blanding av likt og ulikt. Slik er det imidlertid ikke. Forfatteren har lyktes godt med å formidle et samlet, integrert bilde av hvordan han tenker og arbeider med pasienter. Ja, hele hans skrivemåte formidler mye av den holdningen han i teksten vil formidle, nemlig nærvær i øyeblikket og oppmerksomhet på egne følelser og tanker som kan stenge. Dette belyser han dels gjennom kliniske og teoretiske refleksjoner, og dels gjennom en glimrende skrevet fortelling fra en psykoterapi som vi følger gjennom hele boken.

For lesere som vil lære å bruke meditasjonsmetoder fra oppmerksomt nærvær for seg selv eller pasienter, finnes det her klare og meningsfulle instruksjoner.

Slik boken er skrevet, henvender den seg først og fremst til den leseren som vil reflektere over eget liv og eksistens, enten man er student eller fagperson. For psykoterapeuter er det formidlingen av en psykoterapeutisk holdning som er mest verdifull. Som kilde til kunnskaper om psykodynamisk og annen form for psykoterapi, er boken magrere, fordi forfatteren (bevisst?) unngår å sette teoretiske begreper på mange av de intervensjonene han anbefaler.

For kolleger som vil utvikle sin kompetanse for gode pasientsamtaler og/eller avtalt psykoterapi, vil boken kunne gi både inspirasjon og ideer, noen nye ferdigheter og kanskje en litt annen holdning til pasienter med psykiske lidelser. Spander 2-3 timer på denne!

\section{Per Vaglum}

Oslo

\section{Om å høre for folk flest}

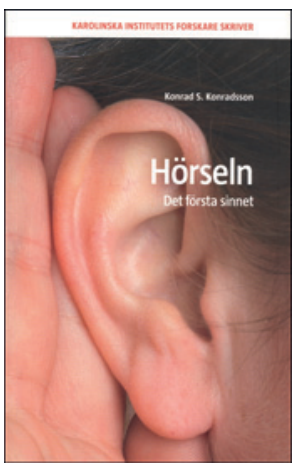

Konrad S. Konradsson

Hörseln

Det första sinnet. 123 s, ill. Stockholm: Karolinska Institutet University Press, 2011.

Pris SEK 198

ISBN 978-91-85565-27-6

Konrad S. Konradsson har tatt for seg det anatomiske og fysiologiske grunnlaget for hørsel i en populærvitenskapelig serie fra Karolinska Institutet hvor forskere skriver om vanlige sykdommer.

Hørselen utvikler seg i siste del av fosterlivet, og dette blir knyttet opp mot utviklingen av talen og evnen til kommunikasjon i vid forstand. Nødvendig habilitering og rehabilitering ved hørselstap har fått en bred omtale, noe som gjenspeiler at dette berører en betydelig del av befolkningen.

Forfatteren forklarer de fysiske egenskapene til lyd og hvordan øret og de sentrale hørselsbanene analyser dette til vår hørsel. Dette gir så mulighet til å forklare hva problemer med hørselen består i. Han gjør rede for ulike typer og årsaker til hørselstap og hvordan hørsel kan måles. Omsorg for døvhet og alvorlig hørselstap hos nyfødte er belyst ved omtale av nyfødthørselsscreening, genetikk ved hørselstap, kokleært implantat, nevronal plastisitet og pedagogisk oppfølging. Høreapparater er viet bred omtale sammen med andre hørselstekniske hjelpemidler og hørselsvern. Øresus, hyperakusis, ototoksisitet, støy og støyskader av hørselen er omtalt ut fra medisinsk biologisk kunnskap.

Illustrasjonene er gode, i farger og med elektronmikroskopiske bilder spesielt tilpasset teksten.

Fremstillingen bygger på oppdatert og evidensbasert kunnskap, i motsetning til en del andre bøker hvor man henvender seg til publikum om hørsel, tunghørthet og andre problemer med hørselen.

Jeg må imidlertid påpeke noen feil: Det mekaniske hørselstapet ved otosklerose er som regel størst i bassområdet, mens hørselstapet ved vokspropp i øregangen er størst i diskantområdet. Magnettomografi er gullstandard for diagnostikk av vestibulært schwannom, og nevrofibromatose type 1 er ikke assosiert med disse svulstene. Kinin er ikke lenger i bruk som malariaprofylakse.

Populærvitenskapelig formidling krever at man ikke kan bruke spesiell terminologi. Presisjonsnivåer kan gå tapt ved omskrivning av vitenskapelig kunnskap til et mer folkelig språk. Forfatteren lykkes ikke alltid i fortolkningen og omskrivningen av originallitteratur, og noen steder er teksten blitt vag. På den annen side gir forfatteren uttrykk for fascinasjon og entusiasme for de nesten ubegripelig fine detaljene som vi møter ved studiet av hørselen.

Boken gir god informasjon om hørsel og medisinsk audiologi for publikum og også for helsepersonell som trenger en kortfattet og moderne fremstilling om hørsel og tunghørthet.

Hans H. Elverland

$\emptyset$ re-nese-halsseksjonen

Nordlandssykehuset Lofoten 